\title{
1066 Analysis of the systemic right ventricle (RV) in patients after atrial switch operation for the correction of complete transposition of great arteries (d-TGA) by MRI
}

\author{
Janine Hoffmann*1, Antje Fleischer ${ }^{1}$, Claudia Fröhlich², Matthias Grothoff ${ }^{3}$, \\ Hashim Abdul-Khaliq ${ }^{4}$, Felix Berger ${ }^{2}$ and Matthias Gutberlet ${ }^{1}$
}

\author{
Address: ${ }^{1}$ Radiology, Heart Center Leipzig, Leipzig, Germany, ${ }^{2}$ Pediatric Cardiology, Heart Center Berlin, Berlin, Germany, ${ }^{3}$ Radiology, Charité, \\ Berlin, Berlin, Germany and ${ }^{4}$ Pediatric Cardiology, University Homburg/Saar, Homburg/Saar, Germany \\ * Corresponding author
}

from I Ith Annual SCMR Scientific Sessions

Los Angeles, CA, USA. I-3 February 2008

Published: 22 October 2008

Journal of Cardiovascular Magnetic Resonance 2008, I0(SuppI I):AI9I doi:I0.I I86/I532-429X-I0-SI-AI9I

This abstract is available from: http://jcmr-online.com/content/I0/SI/AI9I

(c) 2008 Hoffmann et al; licensee BioMed Central Ltd.

\section{Purpose}

To determine morphologic and functional alterations of the systemic ventricle in patients after atrial switch operation for the correction of complete transposition of the great arteries (d-TGA). Right (RV) and left ventricular (LV) volumes were compared with those of normals.

\section{Methods}

MRI examinations were performed in 37 patients (24 male and 13 female) after Mustard/Senning-operation (MSO-atrial switch) to correct d-TGA. A complete set of short axis slices were acquired using steady state free precession sequences on a 1,5 T-scanner (Gyroscan ASC-NT, PowerTrak 6000, Philips). RV and LV parameters were compared between the patient group and normal values.

\section{Results}

Compared to normal values $\left(26 \pm 5 \mathrm{~g} / \mathrm{m}^{2}\right)$ right ventricular muscle mass of MSO-patients $\left(43.6 \pm 16.2 \mathrm{~g} / \mathrm{m}^{2}\right)$ was significantly higher. The stroke volume of patients (33.8 \pm $10.4 \mathrm{ml} / \mathrm{m}^{2}$ ) was significantly lower compared to controls $\left(46 \pm 8 \mathrm{ml} / \mathrm{m}^{2}\right)$. The mean RV ejection fraction of patients $(43,6 \pm 9 \%)$ was also decreased (normal value: $43-63 \%)$. Patients with a stronger hypertrophy of the RV $\left(>40 \mathrm{~g} / \mathrm{m}^{2}\right)$ had a significant higher ejection fraction and a significant lower enddiastolic volume than those with RV muscle mass within normal values $\left(<40 \mathrm{~g} / \mathrm{m}^{2}\right)$ (Fig. 1). Comparing the RV (systemic ventricle) of patients and the LV of controls (systemic ventricle) a significant lower muscle mass was found in patients $\left(43,6 \pm 16,2 \mathrm{~g} / \mathrm{m}^{2} \mathrm{vs} .87 \pm 12\right.$ $\left.\mathrm{g} / \mathrm{m}^{2}\right)$. We also found a significant lower ejection fraction $(43,6 \pm 9 \%)$ and a significant lower stroke volume $(33,8 \pm$ $\left.10,4 \mathrm{ml} / \mathrm{m}^{2}\right)$ in patients compared with controls.

\section{Conclusion}

MRI is useful to examine cardiac morphology and function of patients after MSO (atrial switch) for the correction of d-TGA. The RV hypertrophy is a normal adaption due to the higher blood pressure in the systemic circulation. Patients whose hypertrophy of the right ventricular is more distinctive have better heart function and less heart dilatation. The extent of hypertrophy after MSO may be an important prognostic factor to predict the development of RV insufficiency in these patients. 


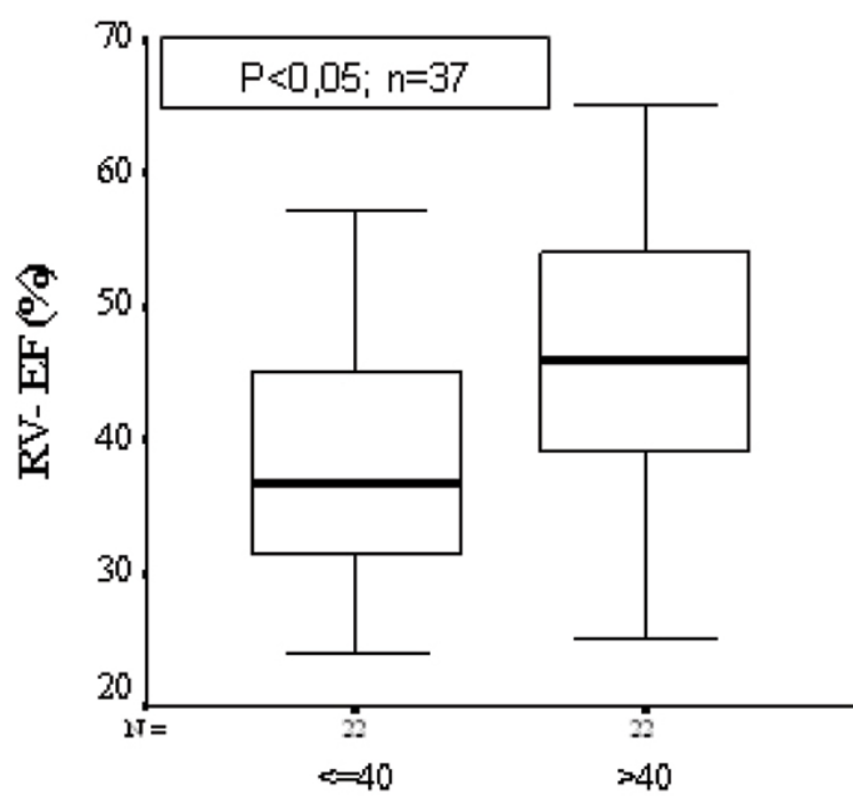

RV-MMI (g'mi)

Figure I

Publish with Biomed Central and every scientist can read your work free of charge

"BioMed Central will be the most significant development for disseminating the results of biomedical research in our lifetime. " Sir Paul Nurse, Cancer Research UK

Your research papers will be:

- available free of charge to the entire biomedical community

- peer reviewed and published immediately upon acceptance

- cited in PubMed and archived on PubMed Central

- yours - you keep the copyright 